\title{
The use of autologous serum tears in persistent corneal epithelial defects
}

AL Young ${ }^{1}$, ACO Cheng ${ }^{2}, \mathrm{HK} \mathrm{Ng}{ }^{3}$, LL Cheng ${ }^{1}$, GYS

Leung ${ }^{1}$ and DSC Lam ${ }^{1,2}$

\begin{abstract}
Purpose Persistent corneal epithelial defects (PED) present a very challenging problem to anterior segment surgeons. Autologous serum tears had been demonstrated to be beneficial in the treatment of PED. The current study was conducted to review the local spectrum of indications and to examine the outcome of autologous serum tear usage.

Methods All cases of PED treated with autologous serum tears at a tertiary referral centre for the period August 1999 - July 2001 were identified and reviewed.

Results A total of 10 eyes from 10 patients were identified (5OD:5OS). The gender ratio was $7 \mathrm{M}: 3 \mathrm{~F}$ and the mean age was 36.8 (range 17-73) years old. The mean duration of PED before the usage of autologous serum tears was $22.4 \pm 69.6$ days. Six eyes healed within 2 weeks, but two eyes failed to heal after 1 month of treatment and two patients defaulted follow-up. No adverse effects were observed with the addition of autoserum tears.

Conclusions The results of the current study correlated well with previous reported studies. Autologous serum tears may be considered as a valuable adjunct in the management of recalcitrant cases of PED.
\end{abstract}

Eye (2004) 18, 609-614. doi:10.1038/sj.eye.6700721

Keywords: autologous serum tears; persistent epithelial defects; limbal stem cell deficiency

\section{Introduction}

Persistent corneal epithelial defects (PED) are one of the difficult conditions encountered by ophthalmologists. They are associated with significant clinical morbidity in patients, resulting in discomfort or visual loss. ${ }^{1}$ The causes of PED are diverse, with several definite aetiologies including dry eyes, limbal stem cell deficiency, diabetes mellitus, and neurotrophic problems. ${ }^{1,2}$ A variety of treatment modalities have been described for PED. The elimination of predisposing-associated risks remains a key factor in the management process. ${ }^{1}$

Conventional treatment includes ocular surface lubrication with frequent instillation of artificial tears, protective glasses, and punctal occlusion. ${ }^{3}$ Essential tears component, such as epidermal growth factor (EGF), vitamin A, transforming growth factor $\beta$ (TGF $\beta$ ), are, however, lacking in artificial tears, as the key constituents of these are water and electrolytes. These essential components can contribute to healing in cases of PED usually associated with an already compromised ocular surface.

Serum has been shown to contain essential tears components in comparable concentrations to natural tears. ${ }^{4}$ Studies have demonstrated that despite the lack of natural tears, the ocular surface epithelium can maintain its phenotype by application of serum alone. An elegant study conducted by Poon et $a l^{5}$ also showed that corneal epithelial cells preserved their cell membrane integrity better (less reduction in cellular viability as measured by ATP assay) when incubated with serum drops in comparison to unpreserved hypromellose. This suggests that serum contains components present in natural tears, and may be used as an adjunct or 'aletrnative' ${ }^{6,7}$

The use of autologous serum tears has previously been demonstrated to have a beneficial effect in the treatment of PED. ${ }^{2,4,5}$ Apart from its usage in treating PED, autologous serum tears may also be used in ocular surface reconstruction and dry eyes from different causes. ${ }^{2,5,8-11}$ Factors present in serum can induce proper proliferation and differentiation of corneal epithelium. ${ }^{12}$
${ }^{1}$ Department of Ophthalmology and Visual Sciences,

The Chinese University of Hong Kong,

Prince of Wales Hospital, Hong Kong SAR,

People's Republic of China

${ }^{2}$ Department of

Ophthalmology and Visual Sciences

The Chinese University of Hong Kong Hong Kong Eye Hospital Hong Kong SAR

People's Republic of China

${ }^{3}$ Department of Anatomical \& Cellular Pathology Prince of Wales Hospital; Hong Kong SAR; People's Republic of China

Correspondence: $\mathrm{Dr} \mathrm{AL}$ Young,

Adjunct Assistant Professor Department of

Ophthalmology \& Visual Sciences,

The Chinese University of Hong Kong, Prince of Wales Hospital, Shatin,

NT, Hong Kong

Tel: + 85226322878

Fax: + 85226482943

E-mail: asmyoung@

netvigator.com

Received: 23 April 2003 Accepted: 21 July 2003

Financial Support: Supported in part by Action for Vision (AFV) Eye Foundation, Hong Kong 
The current study was conducted to review the local spectrum of indications and to examine the outcome of autologous serum tears usage.

\section{Materials and methods}

The design of the study was a retrospective noncomparative case series. Authors have employed various definitions of PED. ${ }^{2,13-17}$ In this study, we adopted the one by Pfister - 'a defect with cells failing to show the expected rate of healing for the time course involved'. ${ }^{17}$

All patients treated with autologous serum tears at the Prince of Wales Hospital, Hong Kong (a tertiary referral centre), from the period August 1999 to July 2001 were reviewed. The underlying diagnoses, duration of PED, additional treatment, indications, frequency, and duration of autologous serum tears usage were documented. The main outcome measures were PED healing time after the initiation of autologous serum tears and if any adverse effects were experienced.

Autologous serum teardrops were prepared by taking $20 \mathrm{ml}$ of peripheral blood from the patient under aseptic technique. The blood was then centrifuged for $5 \mathrm{~min}$ at 1500 revolutions $/ \mathrm{min}$. The serum was separated and was diluted to $20 \%$ with sterile saline. The solution was then put into a bottle with ultraviolet light protective coating on surface. The patients were instructed to store the eye drops in the freezer compartment of domestic refrigerator for no more than 1 month. Previous study reported that the concentrations of vitamin A, EGF and TGF $\beta$ stored at 4 and $-20^{\circ} \mathrm{C}$ could remain stable for 1 and 3 months, respectively. ${ }^{2}$

We adopted the grading system developed by Tsubota et $a l^{2}$ in determining the efficacy of autologous serum tears in the treatment of PED. Autologous serum treatment was considered to be effective if the epithelial defect healed within 2 weeks, partially effective if there was a tendency to heal within 2 weeks and healing achieved in 1 month, and ineffective if healing was not achieved in 1 month.

\section{Results}

A total of 10 eyes in 10 patients were identified. The mean age of the patients was 36.8 (range 17-73) years, with a sex ratio of $7 \mathrm{M}: 3 \mathrm{~F}$ (5OD:5OS). All the patients failed conventional treatment including general measures such as artificial tears, punctal occlusion, and tarsorrhaphy.

The diagnoses yielding limbal stem cell deficiency included Steven Johnson syndrome (one patient), ectodermal dysplasia (one patient), alkaline burns (two patients), sacrificing eye from previous radiation therapy for nasopharyngeal carcinoma (one patient), and postsuperficial keratectomy for pterygium covering the whole cornea (one patient). The remaining diagnoses were neurotrophic ulcers (three patients) and PED after penetrating keratoplasty (one patient). (Table 1).

The mean duration of PED before the commencement of autologous serum tears was $22.4 \pm 69.6$ days (range 1-92 days). In view of the past history of severe recurrent PED and limbal stem cell deficiency in ectodermal dysplasia, patient 3 started autologous serum tears only 1 day after lamellar keratoplasty (Table 1).

The frequency of autologous serum tears ranged from 6 to 14 times per day. In addition, all patients were prescribed preservative artificial tears and preservativefree antibiotics. Other general treatment measures included bandage contact lens in one patient, lateral tarsorrhaphy in three patients, and amniotic membrane transplantation in five patients.

Six eyes healed within 2 weeks and autologous serum tears therapy was considered to be effective. In this 'effective' group, all healed within 1 week after the initiation of autologous serum tears. Two eyes failed to heal within 1 month and autologous serum tears therapy was considered to be ineffective in these patients. No adverse effects (eg induced vascularisation, infection or discomfort) were observed with the application of autologous serum tears (Table 2).

Two patients, however, defaulted follow-up. One patient was lost to follow-up 5 days after the initiation of serum tears. The epithelium was not healed at the last follow-up examination. The second patient selfdiscontinued autologous serum tears after 13 days usage, because he declined further blood taking. The PED was healing with good progress while applying autologous serum tears, but the defect became static after discontinuation of drops. The PED eventually healed after receiving 'conventional' treatment of 2 months.

\section{Discussion}

PED may lead to severe morbidity with potential serious complications. ${ }^{1,2}$ The strategies of treatment for PED include removal of any identifiable aetiologies and promotion of epithelial healing. Any lid abnormalities present such as lagophthalmos, entropion, trichiasis, or chronic blepharitis should be corrected accordingly. Dry eyes should be treated with frequent application of preservative-free medications. Punctal occlusion can preserve natural tears. In addition to their benefit of preventing surface desiccation, essential tears components are also present to promote healing. ${ }^{4}$ In diabetic corneal epitheliopathy, the use of aldose reductase inhibitor has been reported to improve nerve function and corneal sensation, and hence promote 
Table 1 Summary of clinical details of patients

\begin{tabular}{|c|c|c|c|c|c|}
\hline Patient & Diagnosis & Duration of PED (days) & Autologous serum tears & Other treatment measures & Outcome (healing/days) \\
\hline 1 & $\begin{array}{l}\text { Steven Johnson syndrome } \\
\text { (limbal stem cell deficiency) }\end{array}$ & $\begin{array}{l}14 \text { days recurrent PED } \\
2 \text { days AMT }\end{array}$ & $\begin{array}{l}\text { Freq: } 6 x / \text { days } \\
\text { Duration: }>5 \text { days }\end{array}$ & $\begin{array}{l}\text { Ocular lubricants with artificial tears and gel } \\
\text { Topical antibiotics }\end{array}$ & Lost to follow-up \\
\hline 2 & Neurotrophic ulcer, postherpetic & 29 & $\begin{array}{l}\text { Freq: } \mathrm{q} 2 \mathrm{~h} \\
\text { Duration: } 14 \text { days }\end{array}$ & $\begin{array}{l}\text { As per Case } 1+\text { ateral tarsorrhaphy } \\
+ \text { punctal occlusion }\end{array}$ & 6 \\
\hline 3 & $\begin{array}{l}\text { Ectodermal dysplasia } \\
\text { (limbal stem cell deficiency) }\end{array}$ & 1 & $\begin{array}{l}\text { Freq: } 6 x / \text { days } \\
\text { Duration: } 19 \text { days }\end{array}$ & As per Case $1+$ topical steroids & 5 \\
\hline 4 & Alkaline burn, post-AMT & 3 & $\begin{array}{l}\text { Freq: } q 6 \mathrm{~h} \\
\text { Duration: } 4 \text { days }\end{array}$ & $\begin{array}{l}\text { As per Case } 3+\text { oral doxycycline }+ \text { AMT } \\
+ \text { lateral tarsorrhaphy }\end{array}$ & 4 \\
\hline 5 & Postpenetrating keratoplasty & 12 & $\begin{array}{l}\text { Freq: } \mathrm{q} 2 \mathrm{~h} \\
\text { Duration: } 8 \text { days }\end{array}$ & As per Case 3 & 8 \\
\hline 6 & Neurotrophic ulcer (postherpetic) & 17 & $\begin{array}{l}\text { Freq: } 14 \mathrm{x} / \mathrm{d} \\
\text { Duration: }>5 \text { days }\end{array}$ & $\begin{array}{l}\text { As per Case } 1+\text { topical acyclovir ointment } \\
+ \text { punctal occlusion }\end{array}$ & 7 \\
\hline 7 & $\begin{array}{l}\text { Total pterygium excision } \\
\text { (limbal stem cell deficiency) }\end{array}$ & 9 & $\begin{array}{l}\text { Freq: } 6 x / \text { days } \\
\text { Duration: } 8 \text { days }\end{array}$ & As per Case $3+$ punctal occlusion & 7 \\
\hline 8 & $\begin{array}{l}\text { Nasopharyngeal carcinoma with } \\
\text { sacrificing radiation therapy }\end{array}$ & 20 & $\begin{array}{l}\text { Freq: } \mathrm{q} 2 \mathrm{~h} \\
\text { Duration: } 13 \text { days, } \\
\text { then refused }\end{array}$ & $\begin{array}{l}\text { As per Case } 1+\text { punctal occlusion }+ \text { BCL } \\
+ \text { limbal autograft }\end{array}$ & $\begin{array}{l}\text { Reduced in size while in use of tears. } \\
\text { Healed in } 2 \text { months }\end{array}$ \\
\hline 9 & Alkaline burn & 39 & $\begin{array}{l}\text { Freq: } 6 x / \text { days } \\
\text { Duration: } 28 \text { days }\end{array}$ & $\begin{array}{l}\text { As per Case } 3+\text { punctal occlusion }+ \text { BCL } \\
+ \text { AMT }+ \text { lateral tarsorrhaphy } \\
+ \text { oral steroid }+ \text { oral doxycycline }+ \text { Vitamin C }\end{array}$ & 64 \\
\hline 10 & Neurotrophic ulcer & 92 & $\begin{array}{l}\text { Freq: } 6 x / \text { days } \\
\text { Duration: } 43 \text { days }\end{array}$ & $\begin{array}{l}\text { As per Case } 1+\text { patching }+ \text { punctal occlusion } \\
+ \text { conjunctival flap }+ \text { AMT }\end{array}$ & $\begin{array}{l}43 \\
\text { No recurrence }\end{array}$ \\
\hline
\end{tabular}

$\mathrm{BCL}=$ bandage contact lens; $\mathrm{AMT}=$ amniotic membrane transplant. 

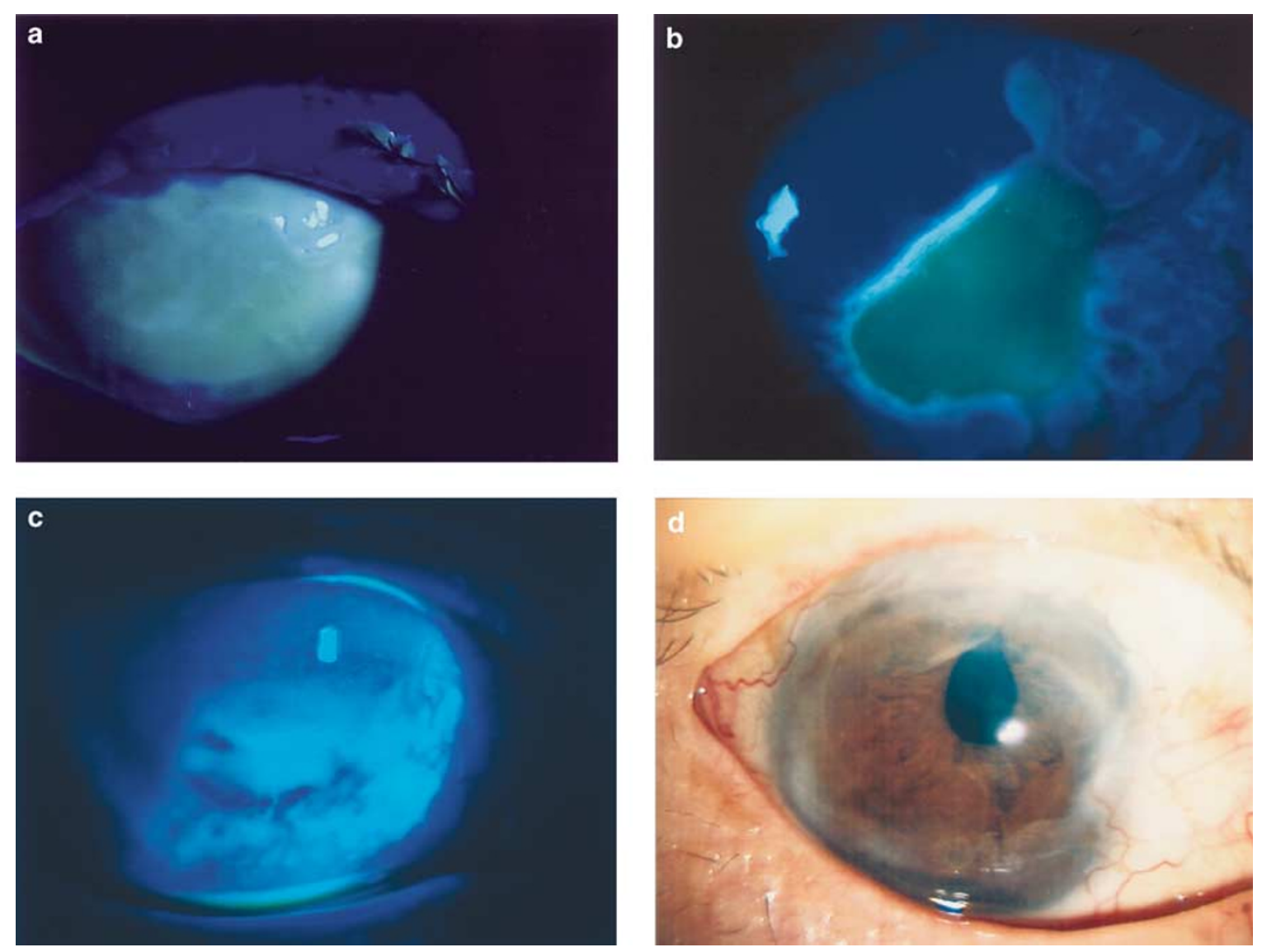

Figure 1 Pre- and post-treatment status of Patent 8. (a) - Subtotal persistent corneal defect after limbal autograft. (b) - After 2 weeks treatment of autologous serum tears. (c) - totally healed defect post-treatment. (d) - taken after 3 years with reasonably stable smooth surface.

Table 2 PED healing time comparison

\begin{tabular}{lll}
\hline Healing within & $\begin{array}{c}\text { Current series } \\
(\mathrm{n}=10)\end{array}$ & $\begin{array}{c}\text { Tsubota }^{2} \\
(\mathrm{n}=16)\end{array}$ \\
\hline 2 Weeks (effective) & $6(60 \%)$ & $7(43.8 \%)$ \\
1 Month (partially effective) & $0(0 \%)$ & $3(18.8 \%)$ \\
$>1$ Month (ineffective) & $2(20 \%)$ & $6(37.5 \%)$ \\
Defaulted & $2(20 \%)$ & $0(0 \%)$ \\
Side effects documented & $0(0 \%)$ & $0(0 \%)$ \\
\hline
\end{tabular}

healing of PED. ${ }^{18}$ Limbal stem cell transplantation has been established as the treatment of choice for limbal stem cell deficiency. ${ }^{19,20}$ Other mechanical aids to facilitate epithelial healing include bandage contact lens (BCL) and tarsorrhaphy. ${ }^{21}$ Both can reduce the mechanical stress of blinking and desquamation of the corneal epithelium. The prolonged contact of the ocular surface to natural tears with its essential components for wound healing has been associated with a significantly faster resolution of PED. ${ }^{15}$ In recent years, amniotic membrane transplantation has also been shown to be useful in the treatment of refractory PED. ${ }^{22,23}$
The exact mechanism of action of autologous serum tears in the promotion of epithelial healing is unknown. It is postulated that essential growth factors for epithelial healing are present. These factors include EGF, vitamin A, TGF $\beta$, and fibronectin. ${ }^{2}$ In addition, neuropeptides such as substance $P$ and insulin-like growth factors are present in the serum. ${ }^{2}$ This may contribute to the relative deficiency of neuropeptides from natural innervation in cases of neurotrophic ulcers. Serum has been shown to accelerate the migration of corneal epithelial cells in vitro, with upregulation of mucin expression. ${ }^{8}$ The presence of serum antiprotease such as $\alpha 2$-macroglobulin, which may inhibit collagenase, may be beneficial in cases with alkaline burn. These findings may account for the beneficial effect from autologous serum tears in the treatment of PED (Figure 1).

The mean duration of PED before starting autologous serum tears was $11.8 \pm 17.2$ days (range 1-29 days) for six patients in the 'effective' group (Table 1). Two patients (patients 9 and 10) failed to heal within 1 month, and treatment was considered to be 'ineffective'. The time for the PED to heal in these two patients were 64 and 43 
days, respectively. The mean duration of PED of these two patients before starting serum tears was $65.5 \pm 26.5$ days (39 and 92 days), which was longer than that of the 'effective group'. It is not known if the delayed commencement of autologous serum tears contributed to the apparent treatment 'ineffectiveness'. As with Tsubota's series, we also observed the tendency of poorer healing when the onset of autologous serum tears treatment was delayed. In comparing our results with the study by Tsubota et al, ${ }^{2}$ our series revealed a larger number of patients in the 'effective' group (43.8 vs 60\%) (Table 2). This may be related to the shorter duration of PED before initiation of serum tears in our group of patients. When both effective and partially effective criteria were included, $62.6 \%$ of the patients healed in Tsubota's group. No adverse effects or toxicities were observed in any of the patients (Tables 3 and 4).

Poon $e t a l^{5}$ (in a prospective cohort case study) demonstrated a success rate in nine out of 15 eyes $(60 \%)$ of PED treated with autologous serum tears. The mean duration of healing was 29 days (ranged 3-60 days). However, the definition of success used was different from the one adopted in this series. Successful treatment was defined as closure of epithelial defect, including defects that healed beyond 1 month. If the duration of time in healing was examined, seven eyes healed within 1 month (46.7\%), corresponding to the effective and partially effective groups, as defined in the current study

Table 3 Comparison of response rate in various underlying pathologies

\begin{tabular}{lcc}
\hline Effective E partially effective & $\begin{array}{c}\text { Current series } \\
\text { (healed/total) }\end{array}$ & $\begin{array}{c}\text { Tsubota }^{2} \\
\text { (healed / total) }\end{array}$ \\
\hline LSCD & $2 / 3$ & $4 / 6$ \\
Post PK & $1 / 1$ & $3 / 4$ \\
Neurotrophic & $2 / 3$ & $2 / 3$ \\
Post-irradiation & $0 / 1$ & $0 / 1$ \\
Alkaline burn & $1 / 2$ & $\mathrm{~N} / \mathrm{A}$ \\
GVHD & $\mathrm{N} / \mathrm{A}$ & $1 / 2$ \\
Total & $6 / 10$ & $10 / 16$ \\
\hline
\end{tabular}

Table 4 Mean duration (days) for healing after initiation of autologous serum tears

\begin{tabular}{lcc}
\hline Diagnosis & $\begin{array}{c}\text { Current series } \\
(\mathrm{n}=10)\end{array}$ & $\begin{array}{c}\text { Tsubota }^{2} \\
(\mathrm{n}=16)\end{array}$ \\
\hline Limbal stem cells deficiency & $6 \pm 1$ & $42.7 \pm 53.3$ \\
Post penetrating keratoplasty & 8 & $37.0 \pm 46.4$ \\
Neurotrophic corneal PED & $18.7 \pm 24.3$ & $37.0 \pm 46.3$ \\
Postirradiation therapy & $60^{\mathrm{a}}$ & 60 \\
Alkaline burn & $34 \pm 30$ & N/A \\
Graft-versus-host disease & N/A & $24.5 \pm 14.8$ \\
\hline
\end{tabular}

${ }^{\mathrm{a} O n l y}$ one patient in this group. and by Tsubota et al. Unfortunately, three patients developed microbial infections that necessitated the stoppage of the autologous serum drops. All the three patients had risk factors that may have contributed to the infections. ${ }^{5}$ No other significant complications were reported with the use of autologous serum tears. ${ }^{5}$

In conclusion, the use of autologous serum tears appears to be a safe and useful adjunctive therapy in resistant cases of PED. The results of the current study correlated well with previous reports. The delayed onset of treatment with autologous serum tears may delay healing.

\section{References}

1 Albert DM, Jakobiec FA Principles and practice of ophthalmology. W.B. Saunders Co.: Philadelphia, 2000.

2 Tsubota K, Goto E, Shimmura S, Shimazaki J. Treatment of persistent corneal epithelial defect by autologous serum application. Ophthalmology 1999; 106: 1984-1989.

3 Hamano T, Ohashi Y, Cho Y, Shimomura Y, Manabe R. A new punctum plug. Am J Ophthalmol 1985; 100: 619-620.

4 Tsubota K, Higuchi A. Serum application for the treatment of ocular surface disorder. Int Ophthalmol Clin 2000; 40: 113-122.

5 Poon AC, Geerling G, Dart JKG, Fraenkel GE, Daniels J. Autologous serum eyedrops for dry eyes and epithelial defects: clinical and in vitro toxicity studies. $\mathrm{Br} J$ Ophthalmol 2001; 85: 1188-1197.

6 Tsubota K, Satke Y, Shimazaki J. Treatment of server dry eye (letter). Lancet 1996; 348: 123.

7 Tsubota K, Toda I, Saito H, Shinozaki N, Shimazaki J. Reconstruction of the corneal epithelium by limbal allograft transplantation for severe ocular surface disorders. Ophthalmology 1995; 102: 1486-1496.

8 Tsubota K, Goto E, Fujita H, Ono M, Inoue H, Saito I et al. Treatment of dry eye by autologous serum application in Sjogren's Syndrome. Br J Ophthalmol 1999; 83: 390-395.

9 Tananuvat N, Daniell M, Sullivan LJ, Qing Y, McKelvie P, McCarty DJ et al. Controlled study of the use of autologous serum in dry eye patients. Cornea 2001; 20(8): 802-806.

10 Fox RI, Chan R, Michelson JB, Belmont JB, Michelson PE. Beneficial effect of artificial tears made with artificial tears made with autologous serum in patients with keratoconjunctivitis sicca. Arthritis Rheum 1984; 29: 577-583.

11 Ogawa Y, Okamoto S, Mori T, Yamada M, Mashima Y, Watanabe $\mathrm{R}$ et al. Autologous serum eye drops for the treatment of severe dry eye in patients with chronic graftversus-host disease. Bone Marrow Transplant 2003; 31: 579-583.

12 Lee SH, Tseng SCG. Amniotic membrane transplantation for persistent corneal epithelial defect with ulceration. Am J Ophthalmol 1997; 123: 303-312.

13 Kim MS, Song SW, Kim JH, Woo HM. Multifocal phototherapeutic keratectomy for the treatment of persistent epithelial defect. J Cataract Refract Surg 2000; 26: 1936-1942.

14 Kaiser PK. A comparison of pressure patching versus no patching for corneal abrasions due to trauma or foreign body removal. Ophthalmology 1995; 102: 1936-1942. 
15 Posenthal P, Cotter JM, Baum JL. Treatment of persistent corneal epithelial defect with extended wear of a fluidventilated gas-permeable scleral contact lens. Am J Ophthalmol 2000; 130: 33-41.

16 Panda A, Pushker N, Bageshwar LM. Lateral tarsorrhaphy: is it preferable to patching? Cornea 1999; 18: 299-301.

17 Pfister RR. Clinical measures to promote corneal epithelial healing. Acta Ophthalmol Suppl 1992; 202: 73-83.

18 Hosotani H, Ohashi Y, Yamada M, Tsubota K. Reversal of abnormal corneal epithelial cell morphologic characteristics and reduced corneal sensitivity in diabetic patients by aldose reductase inhibitor, CT-112. Am J Ophthalmol 1995; 119: 288-294.

19 Kenyon KR, Tseng SCG. Limbal autograft transplantation for ocular surface disorders. Ophthalmology 1989; 96: 709-723.
20 Kenyon KR. Limbal autograft transplantation for chemical and thermal burns. Dev Ophthalmol 1989; 18: 53-58.

21 van Klink F, Alizadeh H, He Y, Mellon JA, Silvany $\mathrm{RE}$ et al. The role of contact lenses, trauma, and Langerhans cells in a Chinese hamster model of Acanthamoeba keratitis. Invest Ophthalmol Vis Sci 1993; 34: 1937-1944.

22 Hanada K, Shimazaki J, Shimmura S, Tsubota K. Multilayered amniotic membrane transplantation for severe ulceration of the cornea and sclera. Am J Ophthalmol 2001; 131: 324-331.

23 Kruse FE, Rohrschneider K, Volcker HE. Multilayer amniotic membrane transplantation for ocular surface disorder. Ophthalmology 1999; 106: 1504-1510. 